Broods of Five Fledglings in the Eurasian Eagle-Owl (Bubo bubo)

Author(s): Juan Manuel Pérez-García, José Antonio Donázar, Fernando

Hiraldo, and José Manuel Sayago

Source: Journal of Raptor Research, 44(2):161-163. 2010.

Published By: The Raptor Research Foundation

DOI: http://dx.doi.org/10.3356/JRR-09-30.1

URL: http://www.bioone.org/doi/full/10.3356/JRR-09-30.1

BioOne (www.bioone.org) is a nonprofit, online aggregation of core research in the biological, ecological, and environmental sciences. BioOne provides a sustainable online platform for over 170 journals and books published by nonprofit societies, associations, museums, institutions, and presses.

Your use of this PDF, the BioOne Web site, and all posted and associated content indicates your acceptance of BioOne's Terms of Use, available at www.bioone.org/ page/terms of use.

Usage of BioOne content is strictly limited to personal, educational, and noncommercial use. Commercial inquiries or rights and permissions requests should be directed to the individual publisher as copyright holder. 


\section{Broods of Five Fledglings in the Eurasian Eagle-Owl (BUBO BUBO)}

KeY WORDS: Eurasian Eagle-Owl; Bubo bubo; brood size, reproductive rate.

The breeding ecology of the Eurasian Eagle-Owl (Bubo bubo) has been subject to numerous studies in different areas of the western Palearctic (Mikkola 1983, del Hoyo et al. 1999, Marchesi et al. 2002, Penteriani et al. 2004) and therefore, the mean and ranges of its breeding parameters are relatively well known. Eagle-owls raise one brood per breeding attempt, although second and replacement clutches have been recorded (Blondel and Badan 1976, Martínez et al. 2003, Ortego 2004, Karyakin 2009), consisting of one to six eggs (Mikkola 1983, del Hoyo et al. 1999). Brood size in eagle-owls varies gradually and inversely with latitude in the European populations (Donázar 1990). These reach the maximum reproductive values in southern Spain, where pairs raising three or four nestlings are 
common (Marchesi et al. 2002). Broods of five fledglings are rarely reported. We have encountered only limited evidence in two publications in which the authors have reported a brood size ranging between one and five (Dalbeck and Heg 2006, Pazhenkov and Korzhev 2006). In this letter, we present the first two records of broods of five fledglings for eagle-owls in Spain, and report another case for Kazakhstan.

On 19 April 2007, we found an eagle-owl nest with a brood of five nestlings in Orihuela, province of Alicante, in southeastern Spain $\left(38^{\circ} 18^{\prime} \mathrm{N}, 0^{\circ} 56^{\prime} \mathrm{W}\right)$. This was the first record of a brood of five nestlings in our study area after $6 \mathrm{yr}$ of monitoring nests (2002-2008; $n=114$ breeding attempts of 66 different pairs). The region where the nest was found is a mosaic dominated by intensive agriculture, Mediterranean shrubs, and Aleppo pine (Pinus halepensis) sparsely distributed. The nest was located in a small cave, $6 \mathrm{~m}$ away from the nestlings and contained abundant prey remains, mainly rabbits (Oryctolagus cuniculus), and pellets. The nestlings were age $30-40 \mathrm{~d}$ based on Penteriani et al. (2005). Although brood-switching has been recorded for this species (Penteriani and Delgado 2008), intrusion of one or more foreign young into another brood generally occurs when fledglings are capable of flight ( $>40 \mathrm{~d}$ old).

The second record was in San Bartolomé de la Torre, Huelva, southwestern Spain $\left(37^{\circ} 27^{\prime} \mathrm{N}, 7^{\circ} 4^{\prime} \mathrm{W}\right)$. The nest was located in a typical Mediterranean habitat dominated by shrubs and sparse Quercus trees. This was the only record of a nest of five found in $12 \mathrm{yr}$ of monitoring of eagle-owl reproduction in this area. On 21 February 2000, the eagle-owl nest contained five eggs. After 32 d, five chicks hatched. By 10 May, all nestlings had fledged successfully. Rabbits are abundant in this area and their remains were found in the nest and in the owls' pellets.

We also collected information on another brood of five fledglings, found during a scientific expedition in the spring of 1999 to eastern Kazakhstan (central Asia; $\left.47^{\circ} 12^{\prime} \mathrm{N}, 79^{\circ} 24^{\prime} \mathrm{E}\right)$. Five fledglings, age $30-40 \mathrm{~d}$, were found in a nest under a rock in a steppe habitat dominated by grasses and forbs. Most of the prey remains found near and in the nest were voles (Microtidae) and medium-sized mammals such as hedgehogs (Hemiechinus auritus) and rodents (Citellus sp., Scirus sp., Alactaga sp., Pygerethmus sp.) and Rosy Starlings (Sturnus roseus; Navarro et al. 2003).

Reproduction is an expensive activity for individuals because it requires an investment of time and energy. Reproductive rate varies with factors such as food supply, population density, and air temperature (Stearns 1992). Lack (1947) proposed that clutch size in birds is limited to the maximum number of young that parents can feed. Therefore, maximum number of offspring is a trade-off between fitness and reproductive costs (Lack 1947), with the upper limit imposed by morphological and physiological constraints (Stearns 1992). Thus, large broods are associated with high prey availability, specifically in these cases rabbits and medium-sized rodents found in Spain and Asian steppes, respectively (Cochet 1999, Penteriani et al. 2002).

I thank Fran and José "El Fonta" for their assistance with the field observations, and I. Zuberogoitia, V. Penteriani, and an anonymous reviewer for their constructive comments on the manuscript.-Juan Manuel PérezGarcía (email address: jperez@umh.es), José Antonio Sánchez-Zapata, and Francisco Botella, Área de Ecología, Dpto. Biología Aplicada, Universidad de Miguel Hernández, Avda, Universidad s/n, E-03202 Elche, Spain; José Antonio Donázar and Fernando Hiraldo, Dept. of Conservation Biology, Estación Biológica de Doñana CSIC, Avda Americo Vespucio s/n, Isla de la Cartuja, E-41092 Sevilla, Spain; and José Manuel Sayago, P.N. Marismas del Odiel, Consejería de Medio Ambiente, Junta de Andalucía, Apdo 720, E-21084, Huelva, Spain.

\section{Literature Cited}

Blondel, J. And O. Badan. 1976. La biologie du Hibou grand-duc en Provence. Nos Oiseaux 33:189-219.

Cochet, G. 1999. Statut et éléments de biologie du Grandduc d'Europe Bubo bubo dans le département de l'Ardéche. Alauda 67:319-322.

Dalbeck, L. AND D. Heg. 2006. Reproductive success of a reintroduced population of eagle owls Bubo bubo in relation to habitat characteristics in the Eifel, Germany. Ardea 94:3-21.

del Hoyo, J., A. Elliott, and J. Sargatal [Eds.]. 1999. The handbook of the birds of the world, Vol. 5. Barn Owls to Hummingbirds. Lynx Edicions, Barcelona, Spain.

DONÁZAR, J.A. 1990. Geographic variation in clutch and brood size of the eagle owl Bubo bubo in the western palearctic. Journal of Ornithology 131:439-443.

KARYAKIN, I.V. 2009. Records on the eagle owls laying the additional eggs to the clutches at the final stage of incubation. Raptor Conservation 15:122-124.

LACK, D. 1947. The significance of clutch-size. Ibis 89:302352.

Marchesi, L., F. Sergio, and P. Pedrini. 2002. Costs and benefits of breeding in human-altered landscapes for the eagle owl Bubo bubo. Ibis 144:164-177.

Martínez, J.A., J.E. Martínez, E. Pérez, I. Zuberogoitia, AND A. IzQuiERdo. 2003. Possible first record of multiple brooding of the eagle owl Bubo bubo. Ardeola 50: $77-79$.

Mikkola, H. 1983. Owls of Europe. T. and A.D. Poyser, Calton, U.K.

Navarro, J., J.A. Sánchez-Zapata, F. Botella, M. Carrete, S. Sklyarenko, A. Gravilov, J.A. Donázar, O. CebalLOS, AND F. HiRALDO. 2003. Diet of three sympatric owls in steppe habitats of eastern Kazakhstan. Journal of Raptor Research 37:256-258.

Ortego, J. 2004. A possible case of double brooding of eagle-owls (Bubo bubo) in Spain. Journal of Raptor Research 38:378-379. 
Pazhenkov, A.S. AND D.A. Korzhev. 2006. Birds of prey and owls of the Shagyray plateau, Kazakhstan. Raptor Conservation 7:56-61.

Penteriani, V. And M.M. Delgado. 2008. Brood-switching in eagle owl Bubo bubo fledglings. Ibis 150:816-819.

M. Gallardo, And M. Ferrer. 2004. Spatial heterogeneity and structure of bird populations: a case example with the eagle owl. Population Ecology 46:185192.

, C. Maggio, A. Aradis, And F. Sergio. 2005. Development of chicks and pre-dispersal behaviour of young in the eagle owl Bubo bubo. Ibis 147:155-168.
, M. Gallardo, And P. Roche. 2002. Landscape structure and food supply affect eagle owl Bubo bubo density and breeding performance: a case of intra-population heterogeneity. Journal of Zoology 257:365-372.

StEARNS, S.C. 1992. The evolution of life histories. Oxford University Press, New York, NY U.S.A.

Received 4 May 2009; accepted 15 November 2009 Associate Editor: Vincenzo Penteriani 